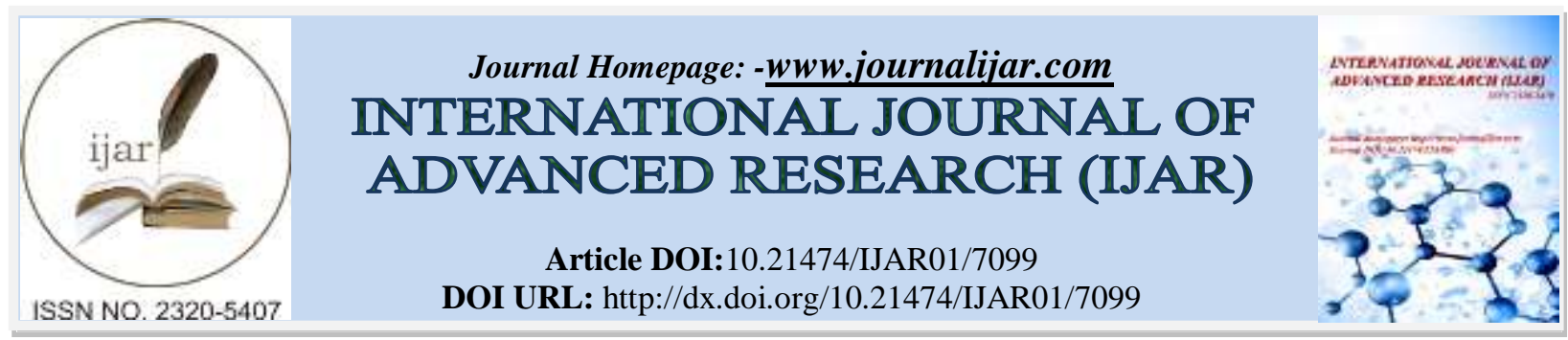

RESEARCH ARTICLE

\title{
INTELLECTUAL PROPERTY RIGHTS AND TRADITIONAL KNOWLEDGE HOLDERS: RELEVANT CASE STUDIES.
}

\section{Rahila Ashraf ${ }^{1}$ and Roohi Mohi-ud-din ${ }^{2}$.}

1. Assistant Professor, Kashmir Tibbia college, Hospital \& Research Centre Taleemabad Shilvath Sonawari, Bandipora-193501 J\&K, India.

2. Ph. D Scholar, Department of Pharmaceutical Sciences, School of Applied Sciences and Technology, University of Kashmir, Hazratbal, Srinagar-190006, J\&K, India.

\section{Manuscript Info}

Manuscript History

Received: 14 March 2018

Final Accepted: 16 April 2018

Published: May 2018

Keywords:-

Traditional knowledge, IPR, Hoodia case, Turmeric patent, Brazzien Berries case.

\begin{abstract}
Intellectual property is a branch of law which protects some of the finer manifestations of human achievements that are of commercial value. Traditional Knowledge (TK), interchangeably used as indigenous knowledge (TK)/ local knowledge generally refer to the matured longstanding traditions and practices of certain regional, indigenous, or local communities that is important in protection, conservation and sustainable use of biodiversity and various traditions. Traditional knowledge and its relationship to the formalIPR system has emerged as a mainstream issue in international negotiations on the conservation ofbiological diversity, international trade, and intellectual property rights including the TRIPSAgreement. This paper briefly presents the various case laws laid down by the international courts as well as in India, in its proper perspective to accord legal protection to Traditional Knowledge.
\end{abstract}

Copy Right, IJAR, 2018,. All rights reserved.

\section{Introduction:-}

Traditional Knowledge (TK), interchangeably used as indigenous knowledge (TK)/ local knowledge generally refer to the matured long-standing traditions and practices of certain regional, indigenous, or local communities that is important in protection, conservation and sustainable use of biodiversity and various traditions (Amend, 2008; Warren et al., 1995; Semali and kincheloe, 2002). Traditional knowledge (TK) is the information that people in a given community, based on experience and adapted to environment and local culture, have developed over time and that continues to develop (Berkes, 1999). This knowledge is used to sustain the community and its culture, as well as the biological resources necessary for the continued survival of the community. It encompasses all species of plants, animals and micro-organisms and variations between them, which form a intangible component of the ecosystems of which they are part. The knowledge and uses of specific plants for medicinal purposes (often referred to as traditional medicine) is an important component of TK. Once, traditional medicines were a major source of materials and information for the development of new drugs. In the 20th century, however, new sources for pharmaceuticals led to a decline in the importance of ethnobotany in drug-discovery programs. However, new discoveries of potentially potent anticancer agents in plants (such as turmeric and taxol), as well as a rapidly growing herbal remedies market, have revived industry interest in traditional medicinal knowledge and practices. As interest in traditional medicine is rekindled, indigenous knowledge of the cultivation and application of genetic resources is being exploited at an alarming rate (Berkes, 2000; Hungtington, 2000; Simali \& Kincheloe). 
Intellectual property is a branch of law which protects some of the finer manifestations of human achievements that are of commercial value. IP (intellectual property) rights should guarantee both a group's and an individual's right to protect and benefit from its own cultural discoveries, creations, and products. An important purpose of recognizing private proprietary rights is to enable individuals to benefit from the products of their intellect by rewarding creativity and encouraging further innovation and invention (Wadehra, 2007).

Since, the international communities are debating the consequences of globalization in its various dimensions in various forums. It is the responsibility of the same international community to debate the means of protection and $n$ preserving TK. In many cases, claims in the patents on plants and their genetic resources are not fundamentally different from the practices applied by the traditional communities in the utilities of these cases of misappropriation have been successfully challenged but others still remains to be challenged. This raises an important issue of legal protection of TK. Thus, present research throws light on the fact that the traditional and contemporary knowledge available with the indigenous people and local communities have and are been used with impunity without recognized the rights of these communities over the benefit that have accorded to user directly or indirectly by examining the case laws available on the subject laid down by the courts in India as well as abroad, in its proper perspective to accord legal protection to Traditional Knowledge. Thus the present paper discusses the various case studies related with intellectual property right and traditional knowledge.

\section{International Cases:- \\ The Hoodia Case:-}

The Xhomani San tribes of the Kalahari are among the oldest communities in Southern Africa. They are holders of traditional knowledge on the use of Hoodia gordonii, a succulent plant found in the Kalahari Desert, which they have historically consumed to stave off hunger on their long journeys. The san peoples were initially unaware that the South African Council for Scientific and Industrial Research (CSIR), an arm of the South African government, had been granted a patent on P57, an appetite suppressant derived of an extract of the Hoodia succulent through research carried out by the CSIR, and had plans to commercialize a Hoodia pharmaceutical product without their consent or their sharing of the benefits derived from the patent and commercialization (Maharaj et al., 2008; Rachel, et al., 2009).

The case serves as an example of the necessity of ensuring PIC of traditional knowledge holders and, in case where such prior informed consent has been achieved and a patent or other form of intellectual property is granted over elements derived from biodiversity of which traditional communities are knowledge holders, ensuring that the benefits of their commercials exploitation are equitably shared.

The Hoodia case also highlights the need to ensure that the national legislation with respect to the biodiversity provides adequate recognition to the rights of traditional communities, in accordance with the principle and objectives set out in the CBD andn the Bonn Guidelines. The Hoodia case highlights the fact that South Africa currently lacks a regulatory framework that can properly ensure the legal protection of the rights of the rural communities over biodiversity, including recognition of PIC and protection of traditional Knowledge. In this regard, it is important to ensure that adequate legislation is developed, whether based on the intellectual property system or a Sui generic model (Vermeylen, 2007; Foster, 2001).

\section{Shaman Pharmaceuticals Case:-}

Shaman Pharmaceuticals, a company located in San Francisco (USA), is integrated indigenous knowledge, modern science and reciprocity into Novel Drug Discovery Approach and focusing on isolating bio-active compound from tropical plants, particularly those which have history of medicinal use (Prabuddha, 2001). Hendricks, J.W. (1988). Its field research teams consists of ethno-botanists, western trained medical doctors, local botanical collaborations, indigenous healers and herbalists. This includes short, medium and long-term reciprocity arrangements.

1. Short-term compensation included building an airship extension in the Ecuadorian Amazon, organizing public health workshops and forest conservation workshops, offering direct medical care to their partner communities and providing clean drinking water system to communities in Ecuador and Indonesia.

2. Medium term approaches have been to provide scholarships and fellowships to scientists working in the field of traditional medicine and also to enhance infrastructural features for research in science and technology for the community. 
As part of their long-term strategy, the company has formed a Healing Forest Conservancy as a nonprofit organization dedicated to conserve cultural and diversity, and sustain the development and management of natural and bio-cultural resources that are part of the heritage of native populations.

\section{Collecting Traditional Medicines in Nigeria:-}

In 1992, three U.S. agencies undertook a programme to collect and experiment on plants and traditional medicines throughout the world. The agencies, the National Cancer Institute, the National Science Foundation and the U.S. Agency for International Development, joined together to form an International Co-operative Biodiversity Group (ICBG) Programme (Lisa, 2001).

One of the project teams under the ICBG programme working in Nigeria devised an interesting arrangement for sharing the benefits arising out of the bio-prospecting of the programme that had been undertaken. The team members agreed to a three-part arrangement for compensating the local people for the traditional knowledge.

1. the team was to ensure that specific monetary benefits reach to the communities at each stage of its research;

2. representatives from these communities were to decide how this money would be spend; and

3. a legal trust was to be created to ensure that the decision taken by the representative were actually implemented.

The royalties earned by the project by making the technologies available to commercial enterprises were to be shared with the communities, with the latter getting at 25 percent share. Fifty percent of this share was to be provided to the local government in whose jurisdiction the project lay, with the other half going to the town or village where the project was located.

Besides these arrangements, the team was to also provide 5 percent of all commercial drug profits to all projects in the particular region on Nigeria where the project was based in order to promote rural health, traditional medicines and biodiversity conservations. The drug company had also to agree to provide the drug at an affordable cost to all Nigerians afflicted with the disease for which the drug was the cure

\section{INBio-Merck Agreement:-}

This case involves the National Institute of Biodiversity of Costa Rica (INBio) and the pharmaceutical manufacturer Merck Sharp and Dohme. It has it's headquarter in the United States. The agreement entered into by the two organizations in 1991 was the first formal attempt to include benefit-sharing arrangement (John, 2000).

Under the terms of the Agreement, INBio had the following obligations:

1. To establish the necessary facilities in Costa Rica for the collection and processing of plants, insects and environmental samples;

2. To provide Merck Sharp and Dohme with a specific number of plants, insects and environmental samples for a period of two years; and

3. To provide for processing of the samples of plants and insects in a laboratory established by INBIO at the University of Costa Rica.

The corresponding obligation of Merck Sharp and Dohme were the following:-

1. Merck was to provide INBIO with a research fund of US\$ 1 million during the first two years of the Agreement and was to contribute to the establishment of laboratories needed for processing of the samples at INBIO and at the University of Costa Rica;

2. Merck was to make an assessment of the samples provided by INBIO through biological experiments owned by Merck to detect potential activity of compounds for use on human and animal health and agriculture; and

3. Merck was to give unique numeric identification to all samples sent by INBIO and was to keep an identification system which would allow the parties to the contract to identify all parties from which there was a possibility of obtaining royalties.

The INBIO- Merck Agreements provided that all inventions arising from the samples supplied by INBIO would belong to Merck. Consequently, the patents on these inventions were also to be taken out by Merck. Although the INBIO-Merck case was the first significant case of benefit-sharing involving the supplies of genetic resources and the commercial interests, the single most noticeable lacuna was the absence of any involvement of local communities. 


\section{Brazzein Berries Case:-}

Brazzein is a sweet-tasting protein extracted from the West African fruits of the climbing plant Oubli. The plant grows in Gabon and Cameron, where the fruit has been consumed by the apes and the natives for a long time.

The Texas companies Prodigene and Nectar World side were among the licensees to use Wisconsin Alumni Research Foundation patent on brazzein, and genetically engineer the enzyme into maize (Someshwar Singh ).

Despite the fact that the sweet taste of the berries was well known in West Africa, the university claims that their production of the sweet compound (brazzein) is its own invention and they don't owe anything to the people of West Africa as they are not legally required to do so. This fact, which involved appropriation of legal rights by means of patents over indigenous biomedical knowledge without compensation to the indigenous groups, is considered by Genetic Resources Action International (GRAIN), Geneva and Green Peace of an act of Biopiracy.

\section{The Enola Bean Patent:-}

U.S. Patent the Enola bean, or yellow bean, patent was granted to John Proctor, the President of seed company POD-NERS, LLC, after he brought the bean seeds back from Mexico (Pallottini et al., 2004). With the patent granted, Proctor has an exclusive monopoly on yellow beans and can exclude the import or sale of any yellow bean exhibiting the yellow shade of the Enola beans. The International Centre for Tropical Agriculture (CIAT) is legally challenging the patent, arguing that the patent claims are invalid, failing to meet novelty and non-obviousness requirements and disregarding available prior art. The USPTO has yet to rule on the re-examination (Danielle, 2003; Neil, 2009).

\section{Indian Cases:-}

\section{The Turmeric Patent Case:-}

Two U.S. based Indian nationals were granted U.S Patent [US Patent 5401504], on the "Use of Turmeric in Wound Healing", which was assigned to the University of Mississippi Medical Centre, U.S.A. The media coverage of the patent generated debate and discussion on the issue, and the Council of Scientific and Industrial Research (CSIR), an autonomous institution under the Department of Science and Technology, Government of India, decided to file for re-examination of the patent. The challenges before CSIR were many. The claimed subject matter was the use of "turmeric powder and its administration", both oral as well as locally applied, for wound healing. It was therefore necessary to find adequate evidence in the form of printed and published in formation that would constitute "anticipation" of the claimed invention (WTO, 1996).

After an extensive search, thirty-two references were located, some of which were more than one hundred years old, and in the languages of Sanskrit, Urdu and Hindi. These were then translated, and authenticated as being true translations. They were then filed as part of the re-examination request, which was admitted by the USPTO as raising substantially new questions of patentability. Based on the references filed, the examiner rejected the claims as being obvious and anticipated, and concluded that the use of turmeric in powder form was an old art of healing (Ganguli, 2001).

\section{Neem Patent Case:-}

The European Patent No. 436257B1was granted to the United States Department of Agriculture and the multinational corporation W.R. Grace in 1995 based on the patent application number 90250319.2 filed on 20.12.1990. The main claim of the patent was: "A method for controlling fungi on plants comprising contacting the fungi with a Neem oil formulation containing 0.1 to $10 \%$ of hydrophobic extracted Neem oil which is substantially free of azadirachtin, 0.005 to $5.0 \%$ of emulsifying surfactant, and 0 to $99 \%$ water. In essence the said patent was for a fungicide made from the seeds of the Neem Tree (EPO, 1997; Cormac, 2005).

In June 1995, a legal opposition against the grand of this patent was filed in the European Patent Office (EPO) by the three groups i.e., the Delhi-based Research Foundation for Science, Technology and Ecology, the Green Party in the European parliament, Brussels, and the international Federation of Organic Agriculture Movements (IFOAM), based in Germany in solidarity with the Neem Campaign.

The main grounds of opposition to the present patent was that the claimed fungicidal effect of hydrophobic extracts of Neem seeds was known and used for centuries on a broad scale in India, both in Ayurvedic medicine to cure dermatological diseases, and in traditional Indian agriculture practice to protect crops from being destroyed by 
fungal infections. Since this traditional Indian knowledge was in fact known to Indians since ancient times, they asserted that the patent in question lacked two basic statutory requirements for the grant of a European patent, namely: "novelty". Article 54 of the European Patent convention (EPC) lays down requirements of novelty (WTO, 1996).

1. An invention shall be considered to be new if it does not form part of the state of the art.

2. The state of the art shall be held to comprise everything made available to the public by means of a written or oral description, by use, or in any other way, before the date of filing of the European patent application.

The opposition panel of the EPO ruled out that patentee's claim of novelty had been destroyed on the basis of clearly demonstrated prior public use.

The second ground that was raised was that the patent was contrary to "morality", because the so-called inventors claimed monopoly property rights on a method which forms part of the TK base of India- in essence stealing it, and theft is regarded as immoral in European culture.

The Neem patent became the first case to challenge European and US patents on ground of biopiracy. The said disputed patent was revoked on the $8^{\text {th }}$ of May, 2005 by the EPO (WTO, 1996).

\section{Basmati Rice Patent Case:-}

Rice Tec Inc, Alvin Texas, USA was issued the Patent on Basmati rice on September 2, 1997 under US Patent No. 5663484.This patent application No. 272353 was filed on July 8, 1994. This caused grave repercussions for India and Pakistan. The Government of India reacted immediately after learning of the Basmati patent issued to Rice Tec Inc. and stated that it would approach the US patent office and urge them to re-examine the patent to a United States firm to grow and sell rice under the Basmati brand name in order to protect India's interests, particularly those of growers and exporters (Braithwaite and Drahos, 2000).

The Patent has been challenged by the Agricultural and Processed Foods Exports Development Authority (APEDA) at the USPTO on behalf of Government of India. The use of the term "Basmati" by Rice Tec has also been challenged on the grounds of inappropriate Trademark usage and violation of "geographical indication". Basmati rice has been grown for centuries in the Greater Punjab Region (India and Pakistan).Furthermore, a high interministerial group comprising of representatives of the Ministries and Departments of Commerce, Industry, External Affairs, Council for Scientific and Industrial Research (CSIR), Agriculture, Bio-technology, All India Rice Exporters Association (AIREA), APEDA and Indian Council of Agriculture Research (ICAR) were mobilized to begin an in-depth examination of the case. The contents and implications of the patent are currently being analyzed in consultation with patent attorneys and agricultural scientists, in the presence of widespread uprising among farmers and exporters; India has felt confident of being able to successfully challenge the Basmati patent by Rice Tec Inc. However, judgements on these issues are awaited with interest (WIPO, 1998).

\section{Wheat Patent Case:-}

Wheat, the Golden grain, is called "Kanak" in North Western India. On $21^{\text {st }}$ May 2003, the European Patent Office in Munich granted a patent to Monsanto under patent no. EP445929, with the sample title "plants", even though are not patentable in European Law. The patent covers wheat exhibiting a special baking quality, derived from native Indian wheat. With the patent, Monsanto hols a monopoly on the farming, breeding, and processing of a range of wheat varieties with low elasticity. The wheat variety which has been pirated from India has been recorded as NapHal in the gene banks from which Monsanto got the wheat and in Monsanto's patent claims. The name NapHal is not the name of an Indian variety. Indian varieties were fully documented by Howard in Wheats of India. NapHal means "no seeds", and cannot be an indigenous seed variety because farmers bred seed to produce seed. NapHal is the name given by W. Koelz, USDA. However, Koelz clearly did not make the collections himself, but was handed over the varieties, since the locations are inaccurate. Thus, the discrepancy in the locations and the name indicate that the variety referred to as NapHal was pirated, not collected. Vandana Shiva, Director of Research Foundation for science, Technology and Ecology (RFSTE) has challenged Monsanto wheat bio-piracy both in the Indian Supreme Court and in the European Patent Office in Munich with Greenpeace. Monsanto's wheat biopiracy patent should be a wakeup call to citizens and governments of the world. It is yet another example of why the TRIPS Agreement need to be changed, and why traditional knowledge and community rights need to be legally recognized and protected (RFSTE, 2004; Vandana, 2004). 


\section{Benefit-Sharing Arrangements with the Kani Tribes of Kerala:-}

This case-study relates to benefit-sharing arrangements arrived at between the Tropical Botanical Garden and Research Institute (TBGRI)- a publicly funded research institute based in Trivandrum- and the Kani tribes of Kerala, involving the medicinal plant called Arogyapaacha (Trichopus zenlanicus). The Kani tribes were using the fruits of this plant as a source of instant energy and vitality. The knowledge related to the plant was divulged by three Kani tribal members to the scientist of TBGRI during an expedition to the forest areas inhabited by the Kanis (Anuradha, 1998; Subramoniam, 1999).

Detailed scientific investigation of the plant was subsequently carried out by the TBGRI, including chemical screeming to isolate the active principles, and pharmacological screening. The TBGRI scientists developed a drug, "Jeevani", by adding three other medicinal plants as ingredients (Pushpangada, 1998).

In November 1997, with the assistance of the TBGRI, a trust was registered named the Kerala Kani Samudaya Kshema Trust. All the nine registered members of the trust were Kani tribesmen. The president and vice-president of the Trust were the two Kanis who imparted the traditional knowledge to the TBGRI regarding Arogyapaacha. The abjectives of the trust are:

1. Welfare and development activities for Kanis in Kerala.

2. Preparation of the biodiversity, Registered to the document the Knowledge-base of the Kanis; and

3. Evolving and supporting methods to promote sustainable use conservation of biological resources.

A first payment of US\$13,000 and royalties of US\$ 500 for the benefit-sharing formula, were deposited in the account of the Kani Samudaya Kshema Trust at Kuttichal Trust Union Bank.

The case involving the Kanis appeared to be a solution towards the evolution of a framework for benefit-sharing with traditional communities at the first instance (WIPO, 1999).

\section{Conclusion:-}

This review explains the various case studies related with intellectual property rights and Traditional knowledge. As the demand on natural resources is continually on the rise, productivity of traditional knowledge in agriculture, food procurement and development of new medicines is plateauing. Using traditional community knowledge to find useful leads and exploiting advances in biotechnology for discontinuous increase in productivity are imperatives for the future. Establishing inventiveness and non-obviousness in patenting of inventions in genetic engineering will continue to challenge legal frameworks. Ownership of knowledge and legal use in cooperative development of pharmaceutical activities, making rapid innovations with quick diffusion in the market place with fair sharing of benefits will be the key means to success. This will require a "mother's" committed touch from governments, NGOs, corporates and communities to create cooperative frameworks for intellectual property rights, respect for community/ traditional knowledge systems and the need to nurture all forms of innovations for the benefit of mankind. However, in the longer term, changes to both the domestic and global IP regimes might be required. Yet, regardless of the exact type of IP rights protection employed, the end result must always be aimed toward a balance, that is, to better protect and provide equitable benefit to the originators of that TK while serving the broader public interest. In other words, access, development, and distribution must be balanced against equitable benefit sharing, sustainable development, and conservation.

\section{References:-}

1. Amend T. (2008): Development needs diversity: People, (Natural resources and international cooperation from the countries of the south), ISBN: 3925064494, 9783725064494, 88.

2. Anuradha, R.V. (1998): Sharing with Kanis: A case study from Kerala, India, New Delhi: Kalpvriksha Mimeo.

3. Berkes, F., Colding, J. \& Folke, C. (2000): Rediscovery of traditional ecological knowledge as adaptive management. Ecol. App. 10(5): 1251-62

4. Berkes, F. (1999): Sacred ecology: traditional ecological knowledge and resource management, (Taylor Francis).

5. Braithwaite, J. and Drahos, P. (2000): Global Business Regulation, Cambridge, Cambridge University Press.

6. Cormac S. (May, 2005): Nature Biotechnology. EPO neem patent revocation revives biopiracy debate. 23(5):5

7. Eberlee, J. (2000-01-21): Assessing the Benefits of Bioprospecting in Latin America. IDRC Reports

8. Foster, L. A. (April 2001): Inventing Hoodia: Vulnerabilities and Epistemic Citizenship in South Africa UCLA Center for the Study of Women: CSW update. 
9. Ganguli, P. (2001): Intellectual Property Rights: Unleashing the Knowledge Economy, New Delhi, TataMcGraw Hill, at 156.

10. Goldberg, D. (2003): Jack and the Enola Bean. TED Case Studies Number xxx. Danielle Goldberg. Retrieved 2013-11-04.

11. Hendricks, J.W. (1988): Power and knowledge: discourse and ideological transformation among the Shuar. American Ethnologist 15(2): 216-238

12. Huntington, H.P. (2000): Using traditional ecological knowledge in science: methods and applications. Ecol. App. 10(5): 1270-74.

13. Pallottini, L., Garcia, E., Kami. J, Barcaccia, G. and Gepts, P. (1 May 2004): The Genetic Anatomy of a Patented Yellow Bean. Crop Science. 44 (3): 968-977.

14. Lisa Onaga. (2001): Cashing in on nature's pharmacy.EMBO Reports 2(4):263-5

15. Maharaj, V.J., Senabe, J.V. and Horak, R.M. (2008): Hoodia, a case study at CSIR. Science real and relevant: 2nd CSIR Biennial Conference, CSIR International Convention Centre Pretoria. 4.

16. Neil (2009-07-22): New legal decision against Enola bean. CIAT: News: Eco-efficiency in Action: Crops @en: Beans @en. International Center for Tropical Agriculture (CIAT). Retrieved 2013-11-04.

17. Pushpangadan, P. (29-31 May, 1996): Tropical Botanical Garden Research Institute: People Oriented Sustainable Development Programme, Paper presented at the UNEP/ GEF Indigenous Peoples' Consultation Meeting, Geneva.

18. Prabuddha Ganguli. (2001): Intellectual Property Rights-Unleashing the Knowledge Economy economy (Tata Mc Graw-Hllpublishing Company New Dehli ), 154.

19. Pushpangadan, P., Rajasekhran, S., Ratheesh Kumar, P. K., Jawahar, C. R., Velayudhan Nair, V., Lakshmi, N. and SaradAmma , L. (1988): Arogyapacha (Trichopus Zeylanicus Gaertn.). The Ginseng of Kani Tribes of Agasthyar Hills (Kerala)for Eevergreen Health and Vitality.Ancient Sci. Life. 7: 13-16.

20. Rachel Wynberg (2004), Rethoric, Realism and Benefit-Sharing: Use of Traditional Knowledge of Hoodia Species in the development of an Appetite Suppressant, The Journal of World Intellectual Property, 4(4): p856.

21. Rachel, W., Doris, S. and Roger, C. (30 September 2009): Indigenous Peoples, Consent and Benefit Sharing: Lessons from the San-Hoodia Case. Springer. ISBN 978-90-481-3123-5. Retrieved 2013-11-04.

22. Simali, L.M. \& Kincheloe, J.L. (2002): What is indigenous knowledge?: voices from the academy, (Routledge).

23. Someshwar Singh. Rampant Biopiracy of South's Biodiversity.

24. Subramoniam, A., Madhavachandran, V., Rajasekharan, S. and Pushpangadan, P. (1997): Aphrodisiac property of Trichopuszeylanicus extract in male mice.J. Ethnopharmacol. 57(1): 21-27.

25. Subramoniam,A., Evans, D.A., Valsaraj, R., Rajasekharan, S. and Pushpangadan P. (1999): Inhibition of antigen-induced degranulation ofsensitized mast cells by Trichopus zeylanicus in mice and rats.J. Ethnopharmacol. 68(1-3):137-143.

26. Tonye Marcelin (2006), Biodiversity Regulatory Options: Involvement of Rural Communities in Decision Making Processes in South Africa. The Journal of World Intellectual Property. 8(6): 809-824

27. Vermeylen Saskia (2007): Contextualizing 'Fair' and 'Equitable': The San's Reflections on the Hoodia BenefitSharing Agreement. Local Environment: The International Journal of Justice and Sustainability. Informa UK Limited. 12(4):423-436. Retrieved 2013-11-04.

28. Warren, D.M., Slikkerveer, L.J. \& Brokensha David, (1995): The cultural dimension of the development: indigenous knowledge systems, (Intermediate technology publications ltd, ITP).

29. WIPO. (2002): Elements of a Sui Generis System for the Protection of Traditional Knowledge. Intergovernmental Committee on IP and Genetic Resources, Traditional Knowledge and Folklore, Third Session. WIPO/GRTKF/IC/3/8.

30. World Intellectual Property Organization (1998): Intellectual Property Reading Material, Geneva, WIPO.

31. World Intellectual Property Organization, Ed. (1999): Intellectual Property and Human Rights, Geneva, WIPO.

32. World Trade Organization -Committee on Trade and Environment (1996): Environment and TRIPS (WT/CTE/W/8) Geneva, WTO [http://www.wto.org]

33. World Trade Organization, Committee on Trade and Environment (1996): Report of the WTO Committee on Trade and Environment, (Press/TE014), Geneva, WTO.

34. Wynberg, Rachel (2013-10-13): Hot air over Hoodia. Grain: Publications: Seedling. Grain. Retrieved 2013-1103. 